\title{
Література:
}

1. Про судову експертизу: Закон України від 25 лютого 1994 року № 4038-XII. URL: http://zakon3.rada.gov.ua/laws/show/4038-12.

2. Кримінальний процесуальний кодекс України [Електронний pecypc]. - Режим доступу: http://zakon2.rada.gov.ua/laws/show/ 4651-17. URL: http://zakon2.rada.gov.ua/laws/show/z1024-17/

DOI https://doi.org/10.30525/978-9934-26-040-7-58

\section{СЛІДОВА КАРТИНА, ЯК ЕЛЕМЕНТ КРИМННАЛІСТИЧНОЇ ХАРАКТЕРИСТИКИ НЕЗАКОННОГО ПОЗБАВЛЕННЯ ВОЛІ}

\author{
Оржинська Е. I. \\ кандидат юридичних наук, \\ доиент кафедри професійних та спеціальних дисииллін \\ Херсонського факультету \\ Одеського державного університету внутрішніх справ \\ м. Херсон, Украӥна
}

Поняття сліду - одне 3 центральних у криміналістиці. Метою дослідження механізмів слідоутворення та їх результатів $є$ отримання доказової інформації про слідоутворюючий об'єкт, його дії або дії $з$ ним, що призвели до утворення сліду. Природа інформації, носіями якої виступають об'єкти слідоутворення, різноманітна. Слідоутворюючий (відображуваний) об'єкт є носієм безпосередньої, первісної інформації, що виражається в сукупності властивих йому індивідуальних і стійких властивостях та ознак. Слідосприймаючий (відображаючий) об'єкт - носій відображеної, похідної від першого об'єкта «вторинної» інформації, що виникла внаслідок їхнього контакту, взаємодії. В результаті дослідженнь слідосприймаючого та слідоутворюючого об'єктів встановлюються причинно-наслідкові зв'язки між ними на підставі їх зв'язку з подією злочину. Проте, слідосприймаючий об'єкт несе інформацію не тільки про відображений об'єкт, а й про механізм слідоутворення. У цьому випадку відображуваний об'єкт є засобом передачі інформації про спосіб, а через нього - і про суб'єкт дії $[1$, c. 110]. Таким чином, сліди при розслідуванні такого виду злочинів, незаконне позбавлення волі, набувають особливої значимості для встановлення повної картини події. Тому при розгляді криміналістичної характеристики незаконного позбавлення волі обов'язковому 
вивченню підлягає питання про сліди злочину, оскільки кожна дія, поведінка людини (в тому випадку і злочинна поведінка) неминуче відображається у навколишньому середовищі та відбивається у ньому, тобто залишає сліди [2, с. 21]. Іншими словами злочинне діяння, вчинюється певним способом, залишаючи закономірні, типові для даного способу чи групи способів матеріальні сліди [3, с. 271].

Матеріальні сліди - криміналістично- реляційна інформація про зміни в матеріальній обстановці, які відбулися в результаті вчинення злочину і виражені сигнально-знакових утвореннях, які являють собою окремі предмети, їх співвідношення, якість, матеріальне вираження, а також належність чи відсутність структурних зв'язків між ними [4, с.22 ].

Типову слідову картину незаконного позбавлення волі складають: традиційні сліди злочинців; сліди предметів, що використовувались для подолання опору потерпілим та сліди в результаті застосування цих засобів; сліди застовування зброї; аудіо- і відеозаписи; цінні папери та інші документи (є найменш типовими) [5, с. 455]

Перш ніж розглянути елементи типової слідової каритини незаконного позбавлення волі звернемо увагу на те, що у справах про незаконне позбавлення волі криміналістичний інтерес представляють собою не тільки сліди злочинців, але і сліди потерпілого. Дуже важливо правильно визначити, які саме сліди і де повинні або могли залишитися в результаті вчинення злочину. Пошук слідів доцільно проводити на місці утримання потерпілого. Необхідно шукати не тільки матеріальні але і ідеальні сліди [6, с. 65].

Найбільш характерними слідами при вчиненні незаконного позбавлення під час огляду місця утримання потерпілого можуть бути: зміни в обстановці місця вчинення злочину (порушення нормального порядку розташування певних речей, відсутність деяких 3 них, присутність предметів невідповідних даній обстановці); сліди які виникли в результаті пошкодження, знищення майна (розбите скло, або побиті чи подряпані двері, що свідчить про наміри потерпілого втекти); сліди, свідчать про надання потерпілим опору (відображаються, як на речах так і в виділені крові) та інше [7, с. 25].

В місцях тримання особи обов'язково залишаються сліди ніг (взуття) злочинців, а у випадку застосування вогнепальної зброї - сліди пострілу. Можуть бути залишені сліди рук, рукавичок.

Крім матеріальних слідів можуть залишатися й ідеальні: свідки могли бачити, як потерпілий входив у приміщення, в якому в подальшому був позбавлений волі.

Процес утримання припускає багаторазові факти контактної взаємодії одягу злочинця з одягом потерпілого. В результаті такої взаємодії 
на одязі потерпілого часто залишаються мікрочастинки одягу злочинця і навпаки.

У місці тримання потерпілого можуть бути залишені (i отже, виявлені) сліди ніг (взуття) потерпілого. Таких слідів не буде тільки в тому випадку, якщо потерпілого принесли в це приміщення на руках $\mathrm{i}$ так само винесли. Можливе виявлення слідів долонь потерпілого. Обов'язково залишаються мікрочастинки його одягу на тих предметах, з якими він вступав у контактну взаємодію: на ліжку, де він лежав, на оббивці крісла де він сидів, на батареї, де він був прикутий, тощо.

Якщо для утримання, обмеження переміщення потерпілого застосовувались наручники, мотузки і тому подібні засоби, на його тілі залишаться садна, потертості, синці, а на цих предметах - клітки епітелію, кров потерпілого.

У випадку прив'язування (приковування) потерпілого до будь-якого предмета (до труб опалення, будівельних конструкцій тощо), на ньому повинні залишатися сліди у вигляді подряпин, слідів тертя, мікрочастинок фарби, наручників, мікро волокон мотузки, а на мотузці (наручниках) - мікрочастки (або частки фарби) предмета до якого вони прикріплювалися.

Якщо розглядати як сліди вчиненого злочину тілесні ушкодження, то вони у випадку незаконного позбавлення волі відрізняються певною своєрідністю.

Для потерпілих характерні тілесні ушкодження, отримані:

-у разі подолання вчиненого ними опору (сліди боротьби або самооборони) - синці, садна на обличчі, тулубі, кінцівках.

- у разі зв'язування - садна і синці (але вже трохи іншої локалізації: на руках - в області зап'ясть, ліктьових суглобів, на плечах; на ногах найчастіше в області гомілковостопних суглобів).

Холодна і вогнепальна зброя використовується, в основному, тільки для залякування потерпілого, для попередження можливого активного опору, а не для заподіяння шкоди здоров'ю. Слідами застосування психічного насильства до потерпілого є стрес, фізіологічні і психічні травми [8, с. 65].

Тілесні ушкодження можуть бути виявлені і на злочинці, якщо $\epsilon$ підстави вважати, що йому був вчинений опір потерпілим. Такі сліди можуть бути у вигляді синців: на обличчі, тулубі, кінцівках [9, с. 148].

Необхідно зазначити, що, нажаль на практиці, через різноманітність способів позбавлення волі слідова «картина» в більшості випадків являється вкрай обмеженою через ряд причин: про позбавлення волі стає відомо через деякий час, тому розслідування починається зі спливу довгого періоду часу; огляд місця утримання в більшості випадків не 
проводиться, тому сліди зникають у часі, розсіюються у просторі (важливі обставини забуваються) тощо [10, с. 225].

Отже, сліди при розслідуванні незаконного позбавлення волі набувають особливої значимості для встановлення повної картини події. Так у справах даного виду злочину криміналістичний інтерес представляють собою не тільки сліди злочинців, але і сліди потерпілого. Пошук слідів доцільно проводити на місці утримання потерпілого. Необхідно шукати не тільки матеріальні але і ідеальні сліди.

\section{Література:}

1. Костенко М.В. Криміналістична характеристика вбивств на замовлення: дис... канд. юрид. наук: 12.00.09. Харків, 2003. 227 с.

2. Лук'янчиков Б.С. Слідчі ситуації у побудові поза видових методик розслідування. Науковий вісник Національної академії внутрішніх справ Украӥни. 2000. № 3. С. 180-187.

3. Советская криминалистика: Методика расследования отдельных видов преступлений / В. К. Лисиченко., В. И. Гончаренко, М. В. Салтевский и др.; Под. ред В. К. Лисиченко. Київ: Вища шк. Головне изд-во. 1988. 405 с.

4. Лук'янчиков Б.Є. Слідчі ситуації у побудові поза видових методик розслідування. Науковий вісник Наџіональної академії внутрішніх справ Украӥни. 2000. № 3. С. 180-187.

5. Бурлака В.В. Криміналістична характеристика незаконного позбавлення волі або викрадення людини. Митна справа. 2014. № 6 (69). Ч. 2. Кн. 2. С. 451-456.

6. Олішевський В.В. Розслідування та попередження викрадення людини, вчинене 3 корисливих мотивів: дис... канд. юрид. наук: 12.00.09. Харків, 2005. 213 с.

7. Лук'янчиков Б.С. Слідчі ситуації у побудові поза видових методик розслідування. Науковий вісник Національної академіі внутрішніх справ Украӥни. 2000. № 3. С. 180-187.

8. Олішевський В.В. Розслідування та попередження викрадення людини, вчинене 3 корисливих мотивів: дис... канд. юрид. наук: 12.00.09. Харків, 2005. 213 с.

9. Овчинникова Г.В., Павлик М.Ю., Коршунова О.Н. Захват заложника: уголовно-правовые, криминологические и криминалистические проблемы. Санкт-Петербург: Издательство «Юридический центр Пресс» 2001. 259 с.

10. Соколова Я.А. К вопросу об элементах криминалистической характеристики преступлений, связанных с незаконным лишением свободы. Проблеми законності: Республіканський міжвідомчий наук. Збірник. Харків: Нац. юр. академія України. 1999. Вип. 37. С. 220-225. 